\title{
Analysis of the calibration quality of the Kyviškès Calibration Baseline
}

\author{
Arūnas Būga ${ }^{1} \mathbb{D} \cdot$ Rosita Birvydienè $^{1} \cdot$ Ričardas Kolosovskis $^{1} \cdot$ \\ Boleslovas Krikštaponis ${ }^{1} \cdot$ Romuald Obuchovski $^{1}$ • \\ Eimuntas Paršeliūnas ${ }^{1} \cdot$ Raimundas Putrimas $^{1}$ • \\ Dominykas Šlikas ${ }^{1}$
}

Received: 20 March 2015/Accepted: 5 August 2015/Published online: 19 August 2015 (C) Akadémiai Kiadó 2015

\begin{abstract}
The authors of the paper present analysis of the baseline calibration results that they have performed. The Kyviškès Calibration Baseline $(1320 \mathrm{~m})$ is the longest calibration baseline in Lithuania. The baseline was established by the Institute of Geodesy, VGTU in 1996 for calibration of the EDM instruments. The Finnish Geodetic Institute together with the Institute of Geodesy, VGTU is calibrating the Kyviškès Calibration Baseline regularly. The first time these measurements were performed in 1997 and repeated in 2001, 2007, 2008 and 2014. The same Kern Mekometer ME5000 EDM instrument was used for all the measurements performed. By building additional pillar aside from the baseline pillars the Kyviškès Baseline was converted to a triangle-shaped test field in 2000. The results confirm good stability of the baseline, which is now used for calibration of the EDM instruments, total stations and GNSS receivers. The calibration results reveal a slight variation in the baseline length correlated with temperature changes.
\end{abstract}

Arūnas Būga

buga@vgtu.lt; arunas.buga@vgtu.lt

Rosita Birvydienè

rosita.birvydiene@vgtu.lt

Ričardas Kolosovskis

ricardas.kolosovskis@vgtu.lt

Boleslovas Krikštaponis

boleslovas.krikstaponis@vgtu.lt

Romuald Obuchovski

romuald.obuchovski@vgtu.lt

Eimuntas Paršeliūnas

eimis@vgtu.lt

Raimundas Putrimas

raimundas.putrimas@vgtu.lt

Dominykas Šlikas

dominykas.slikas@vgtu.lt

1 Institute of Geodesy, Vilnius Gediminas Technical University, Vilnius, Lithuania 
Keywords Electronic distance measurement - Calibration baseline - Calibration of EDM instruments

\section{Introduction}

By performing EDM instrument calibration or verification three errors can be determined-additive constant, scale error, cyclic error (Rüeger 1985). The calibrated instrument allows correcting the above mentioned errors.

Distance measurement, as well as leveling rod calibration, cannot be performed without connection to the national length standard. Such connection for distance measurement provides foundation for calibrating laser scanners, cameras and GNSS equipment. Numerous EDM instrument calibration baselines were built during the recent decades.

National Geodetic Survey (NGS) of the USA conducts a cooperative program that provides surveyors with means to detect and correct errors in EDM instruments. NGS has established more than 300 EDM instruments calibration baselines throughout the United States in cooperation with various government agencies, universities, professional societies, etc. Established baselines are regularly calibrated in the USA. This has created preconditions for the US surveyors to have a locally accessible standard for the length measurement (Dracup et al. 2014).

In Canada, calibration baselines are calibrated using Kern Mekometers ME5000 at regular intervals. In Finland, calibration baselines are calibrated for over 50 years already. In New Zealand, calibration baselines are re-calibrated annually using Mekometers, and the data and software for individual user calibration are available free over the internet, updated early after the re-calibration (Hazelton 2009). Australia also has a requirement for an annual EDM calibration. In Australia, according to the Cadastral Surveys Regulations of 2005, EDM equipment used on any survey must be maintained and compared to a standard of measurement, and calibration should be performed every year and after every repair of the instrument.

The EDM instruments should be verified with a period of 2 years according to the regulations of the Ministry of Economy of the Republic of Lithuania. The Calibration laboratory of the Institute of Geodesy, VGTU is performing periodic verification of the EDM instruments. Many customers would like to have an EDM calibration certificate as well, therefore along with verification, calibration of the EDM instrument is performed and the calibration certificate is issued.

In the publication we cover the history of the Kyviškès Calibration Baseline and provide information on the baseline calibrations as well as results of the analysis revealing some interesting peculiarities.

\section{Measurements of the Kyviškès Calibration Baseline}

The purpose of establishing the Kyviškès Calibration Baseline was to create calibration facilities for the EDM instruments. A suitable site was selected in the Kyviškeis airfield (functioning since 1947), which is still used for pilots' training. The Kyviškès airfield was assigned to the VGTU in 2009. The flat unobstructed area of the airfield is very fitting for the calibration baseline. The area of the airfield and the Kyviškès Calibration Baseline was fenced by metal net limiting possible access for strangers. 
Six observation pillars were built on the grassland on the western side of the airfield (Fig. 1).

The pillars (Fig. 2) are fundamented $3.25 \mathrm{~m}$ below the ground surface. An insulated steel pipe is anchored using reinforced concrete. The soil in Lithuania never freezes bellow $1.5 \mathrm{~m}$ in winter. The topsoil texture is mostly composed of sand and sandy loam in Kyviškès, which is typical for this part of Lithuania. 6 observation pillars are built in line deflecting around $10^{\circ}$ from the North-South direction. The baseline extends up-slope with an approximate grade of $0.5 \%$ from 1 to 6 pillar.

The distances from the first to the following pillars are 100, 360, 1120, 1300 and $1320 \mathrm{~m}$ respectively. Ten more calibration line combinations are possible from other than the first pillar. The seventh pillar was built in 2000 on the eastern side of the runway, 644-949 m from the other pillars. By building the seventh pillar additional 6 observable distances in the test field were created. All the seven observation pillars are not protected from the direct Sun.

The Kyviškès Calibration Baseline is the longest $(1320 \mathrm{~m})$ calibration baseline in Lithuania and among the several ones most frequently calibrated in Europe recently. The Kyviškès Calibration Baseline was established by the Institute of Geodesy, VGTU in 1996 for the calibration of the EDM instruments (Jokela et al. 1999). The Finnish Geodetic Institute together with the Institute of Geodesy, VGTU are measuring the Kyviškès Calibration Baseline in 5-7 year cycles.

The surveying activities are becoming increasingly international recently. Surveyors take part in the international projects and participate in the tenders where positioning

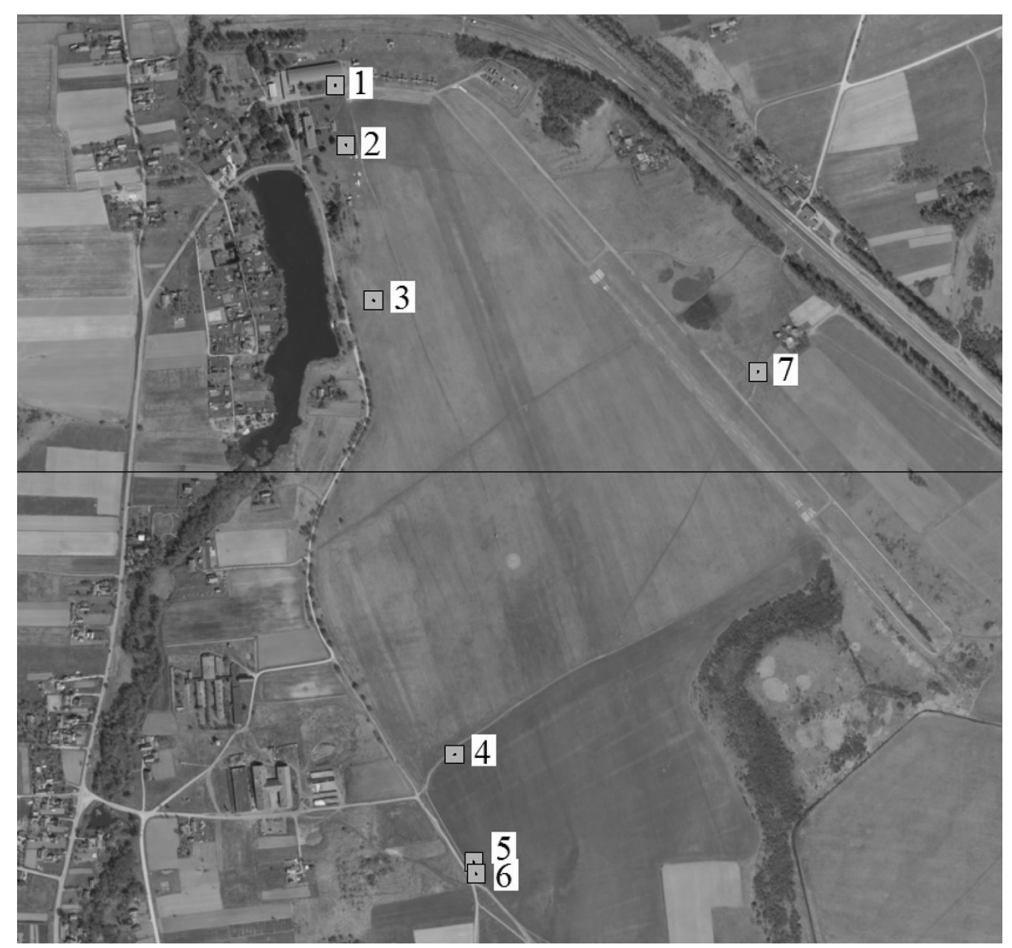

Fig. 1 Orthophoto of the Kyviškès Calibration Baseline 


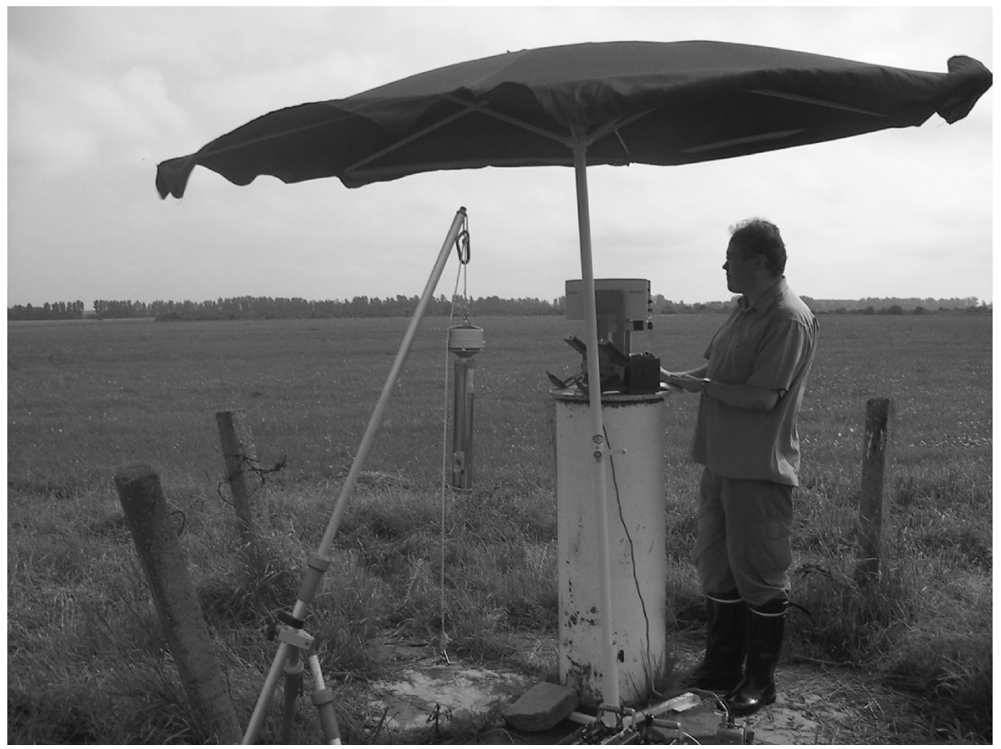

Fig. 2 The pillar occupied with the Mekometer, barometer and shaded thermometers

techniques are applied. Moreover, the accredited calibration and testing laboratories have to demonstrate their proficiency. The proficiency testing (comparative calibration or testing) is an important way of meeting the requirements of the ISO/IEC 17025 in the area of quality assurance of the laboratory results. Therefore the EDM calibration baselines in different countries are required.

Along with establishing of the seventh pillar and extending the calibration baseline to a triangle-shaped test field in 2000 the preconditions were created to use baselines for testing GPS receivers, theodolites, total stations and laser scanners. Such methodology was

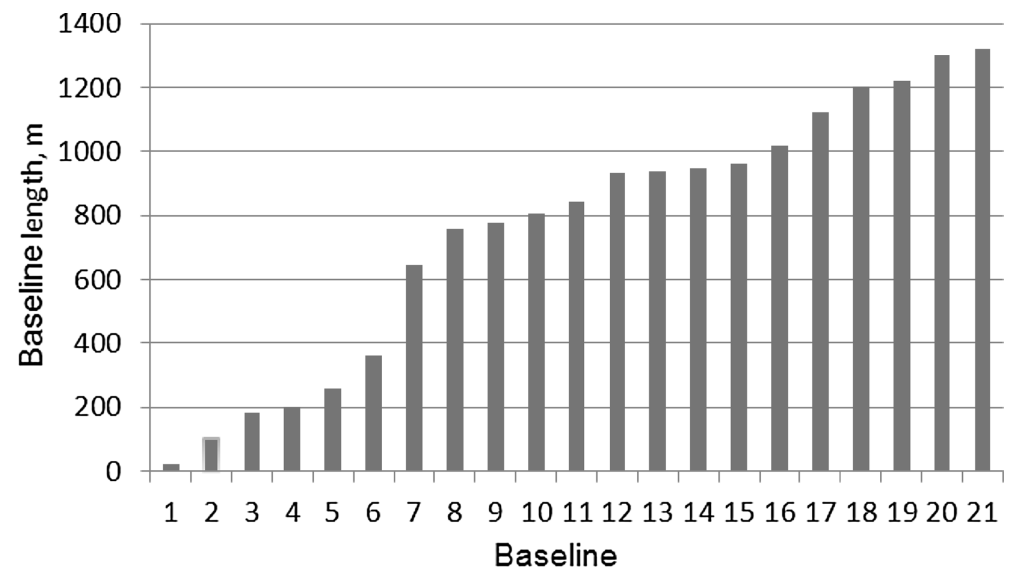

Fig. 3 The possible combinations of the baseline length in the Kyviškès test field since 2000 
recently suggested (Šlikas 2013). By building the 7th pillar the test field acquired 21 different possible baseline combinations (Fig. 3).

The same Kern Mekometer ME5000 was used for all measurements performed from 1997 till 2014. The Mekometer was regularly calibrated at the Nummela Standard Baseline, which is measured with the Väisälä white light interference comparator (total standard uncertainty $\pm 0.09 \mathrm{~mm} / \mathrm{km}$ in the traceability chain to the definition of the metre) (Jokela and Häkli 2006).

The Väisälä interference comparator, an instrument using white light interferometry was invented by academician Yrjö Väisälä in the 1930s. In long distance measurements the comparator still beats in accuracy the state-of-the-art electronic distance measurement instruments. Measuring the baselines with the Väisälä comparator takes advantage of quartz gauges ( $1 \mathrm{~m}$ long bars made of quartz and with spherical end surfaces). The quartz gauges give an accurate scale for the Väisälä comparator (Kukkamäki 1978).

The expanded uncertainty of the scale transfer to the Kyviškès Baseline never exceeded $\pm 0.9 \mathrm{~mm}$ since 1997. After upgrading the Kyviškès Baseline was extended to a triangleshaped test field in 2000, and four cycles of re-measurements of the newly created combination of the baselines were made in 2001, 2007, 2008 (Būga et al. 2011) and 2014. Though obtained results prove high accuracy of the determined length of the Kyviškès Calibration Baseline, we noticed the baseline lengths minor variations, which are air temperature correlated. The possible reason for this is discussed below.

The repeated high precision measurements traceable to the Finnish National Standard are essential in proving stability and reliability of the Kyviškès Calibration Baseline. The baseline of the Finnish Geodetic Institute (FGI) at Nummela, Finland, has been well established for decades and is the reference for a number of high-precision baselines all over the world, including the newest in Austria, Estonia and Germany (Pollinger et al. 2012).

The lengths at Kyviškès are traceable to the definition of the meter (Fig. 4). The Nummela Standard Baseline in Finland, measured regularly with the Väisälä interference comparator, and the quartz gauge system determining the scale in it, are essential measurement standards in the traceability chain (Jokela and Poutanen 1998). The scale is transferred from Nummela to Kyviškès with a high precision EDM instrument Kern

Fig. 4 The traceability chain of the Kyviškès Baseline

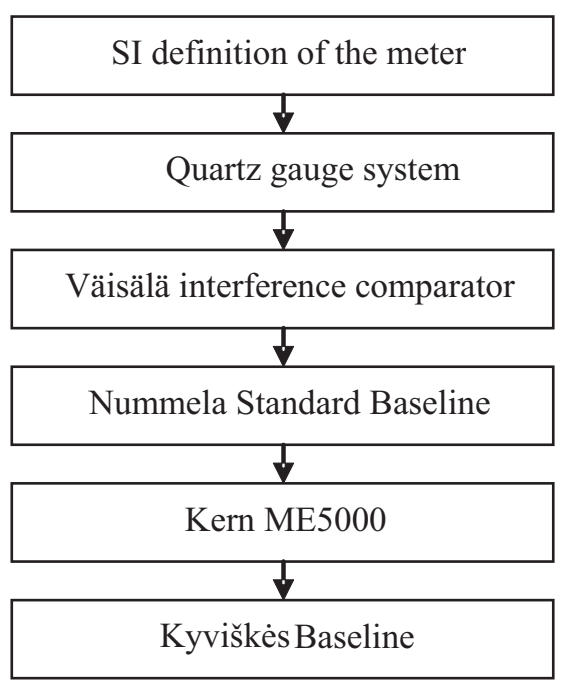


ME5000 (Mekometer) of the Laboratory of Geoinformation and Positioning Technology of the Helsinki University of Technology (currently Aalto University).

The transfer standard, Kern ME5000 high precision EDM instrument (no. 357094) with prism reflector (no. 374414) was calibrated at the Nummela Standard Baseline. There Kern ME5000 scale correction varied from -0.014 to $+0.316 \mathrm{~mm} / \mathrm{km}$ and additive constant from +0.034 to $+0.140 \mathrm{~mm}$ during 1997-2014.

For the scale transfer to Kyviškès, true distances from interference measurements in 1996 were used in 1997 and 2001. In 2007 true distances from interference measurements in 2005 were used and in 2008 true distances from interference measurements in 2007 (Jokela and Häkli 2010). Standard errors of the true distances $24-864 \mathrm{~m}$ are \pm 0.03 to $\pm 0.07 \mathrm{~mm}$. In 2005, only half of the Nummela Standard Baseline, $432 \mathrm{~m}$, could be measured, because of constantly unfavorable weather conditions. The complete interference measurements were performed in 2007 and 2013 up to $864 \mathrm{~m}$. The results fit very well as well as in the 60 years' time series; the standard uncertainty of the $864 \mathrm{~m}$ length is below $0.1 \mathrm{~mm}$ (Jokela 2014).

In Kyviškès, forced centering employing cone screws in order to fix instrument and reflector to the top plates of the pillars was used. Velocity corrections for the displayed distances were computed using the weather data obtained by calibrated instruments. Every Mekometer 5000 measurement was followed by dry and wet temperature measurements at the EDM instrument with an Assmann psychrometer and air pressure with a Thommen aneroid barometer. reading accuracies were $\pm 0.1{ }^{\circ} \mathrm{C}$ and $\pm 10 \mathrm{~Pa}$, respectively. Supplementing temperature observations were performed at the reflector (Jokela et al. 2009). During measurements, the thermometers used with Assmann psychrometers were shaded at the instrument height (Fig. 2).

\section{Stability of the Kyviškès Calibration Baseline}

The Fig. 5 presents variations in the length of the Kyviškès Calibration Baseline with reference to the first measurements in 1997. Slight but noticeable variations could be caused by the altering temperature, as the baseline calibrations were performed in June

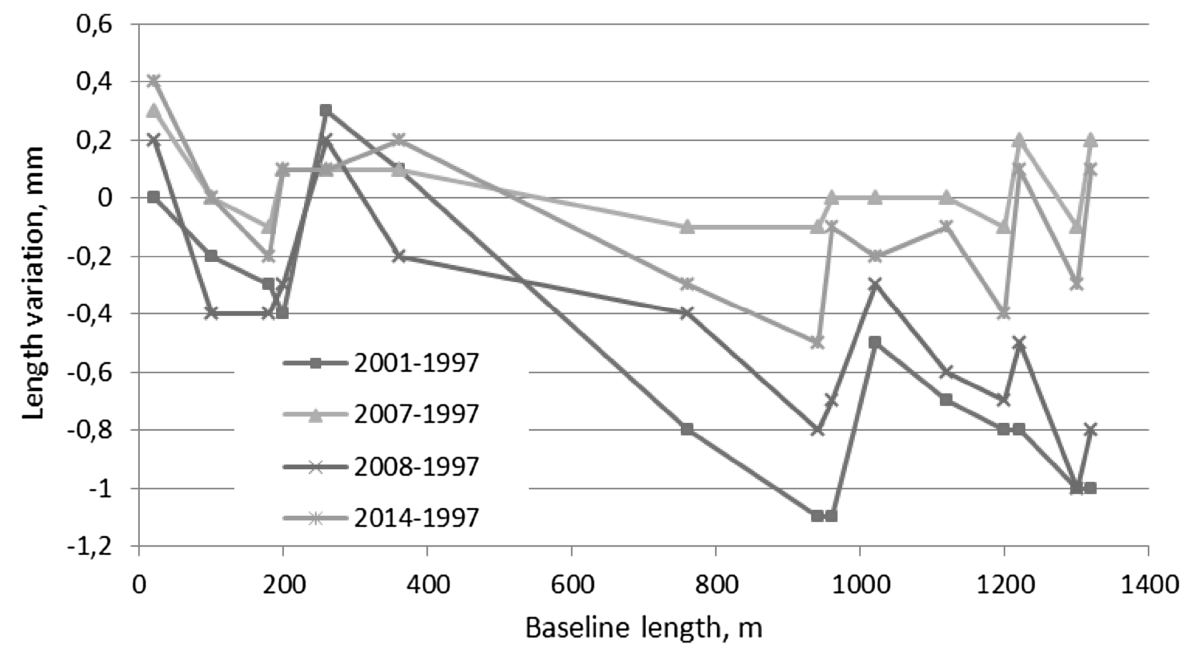

Fig. 5 The Kyviškès Baseline length variations 
1997, October 2001, August 2007, October 2008, and July 2014. The temperatures almost matched during the calibrations in June 1997, August 2007 and July 2014, as well as during calibrations performed in October 2001 and October 2008. It should be noted that the maximum variation of length of the baseline sections reached $1.2 \mathrm{~mm}$ during five measurement cycles, but for the most of the baseline sections it was below $0.7 \mathrm{~mm}$.

Analysis of five calibration cycles of the Kyviškès Baseline revealed minor variations in the determined baseline section lengths. Comparison of every measurement cycle with the previous one reveals obvious fluctuations between them (Fig. 6). These fluctuations could be related to the seasonal temperature changes that were not completely taken into account during the baseline processing. Every baseline combination (21 line in total) is marked with different colour and listed from the shortest one on top $(20 \mathrm{~m})$ to the longest one at the bottom $(1320 \mathrm{~m})$, and respectively from left to right for every period of analysis.

In Fig. 6, the swinging nature of the baseline length variations can be noticed. It could be related to the seasonal temperature fluctuations. An equilibrium point here is the length of the baseline measured during the previous cycle of observations.

\section{The Kyviškès Calibration Baseline length variation in relation to the temperature changes}

According to the obtained results the atmospheric conditions registered during the campaigns were analysed. The air temperatures of every measurement cycle were averaged, and the determined baseline lengths were compared. Mean temperature variation between the measurement cycles in 1996, 2001, 2007, 2008 and 2014 reached $22{ }^{\circ} \mathrm{C}$, while the

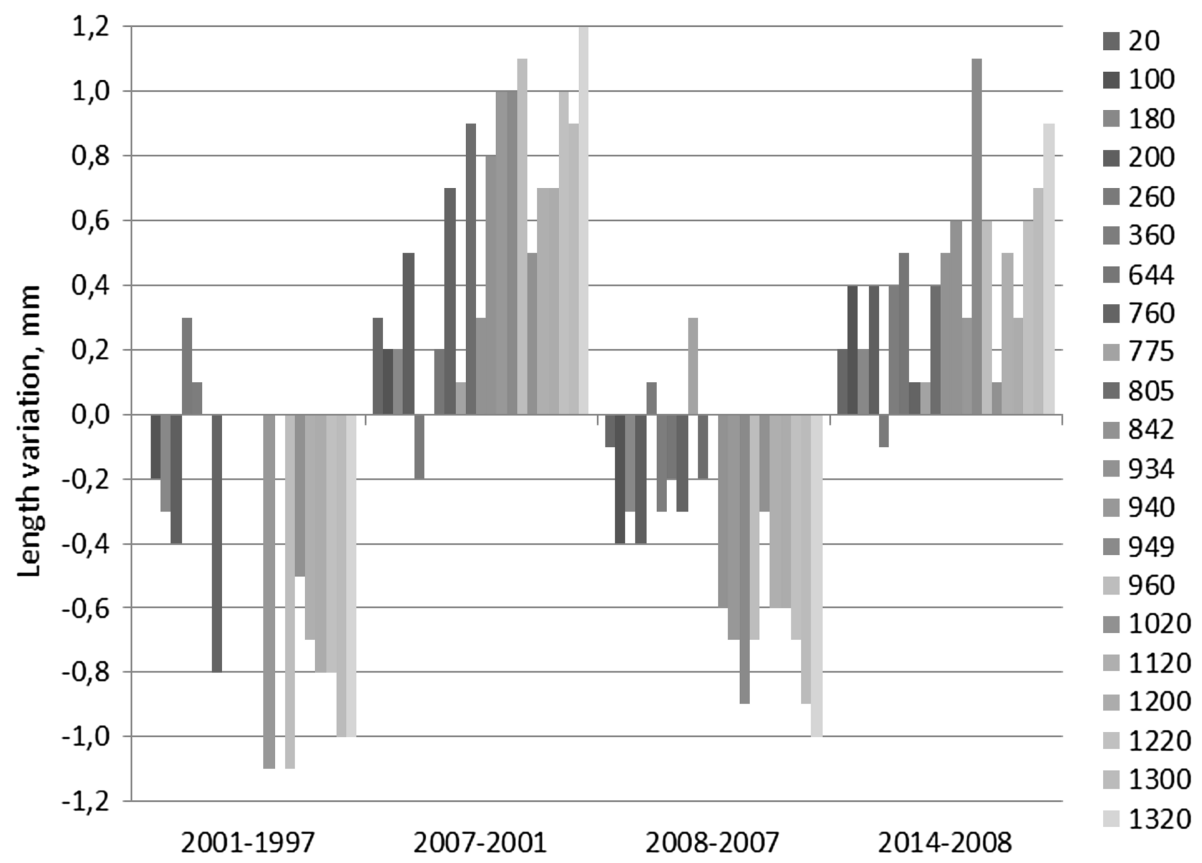

Fig. 6 The Kyviškès Baseline length variations in different periods 
extremes during 5 observation cycles exceeded $33{ }^{\circ} \mathrm{C}$. The relation between the baseline length variation and the air temperature is obvious (Fig. 7).

According to the obtained results, the graph showing dependency of the baseline elongation on the baseline length was created (Fig. 8).

The baseline length is evidently temperature correlated. The correlation coefficients computed for the individual baselines calibrated in 1997-2014 are listed in the Table 1.

The accuracy of the high precision EDM (Kern Mekometer ME5000) is $0.2 \mathrm{~mm}+0.2 \mathrm{ppm}$. Yet it is very important to observe precisely the atmospheric parameters in order to achieve the declared instrument accuracy. An error of $1{ }^{\circ} \mathrm{C}$ in the air temperature causes about 1 PPM error in the light wave measurement. The distance
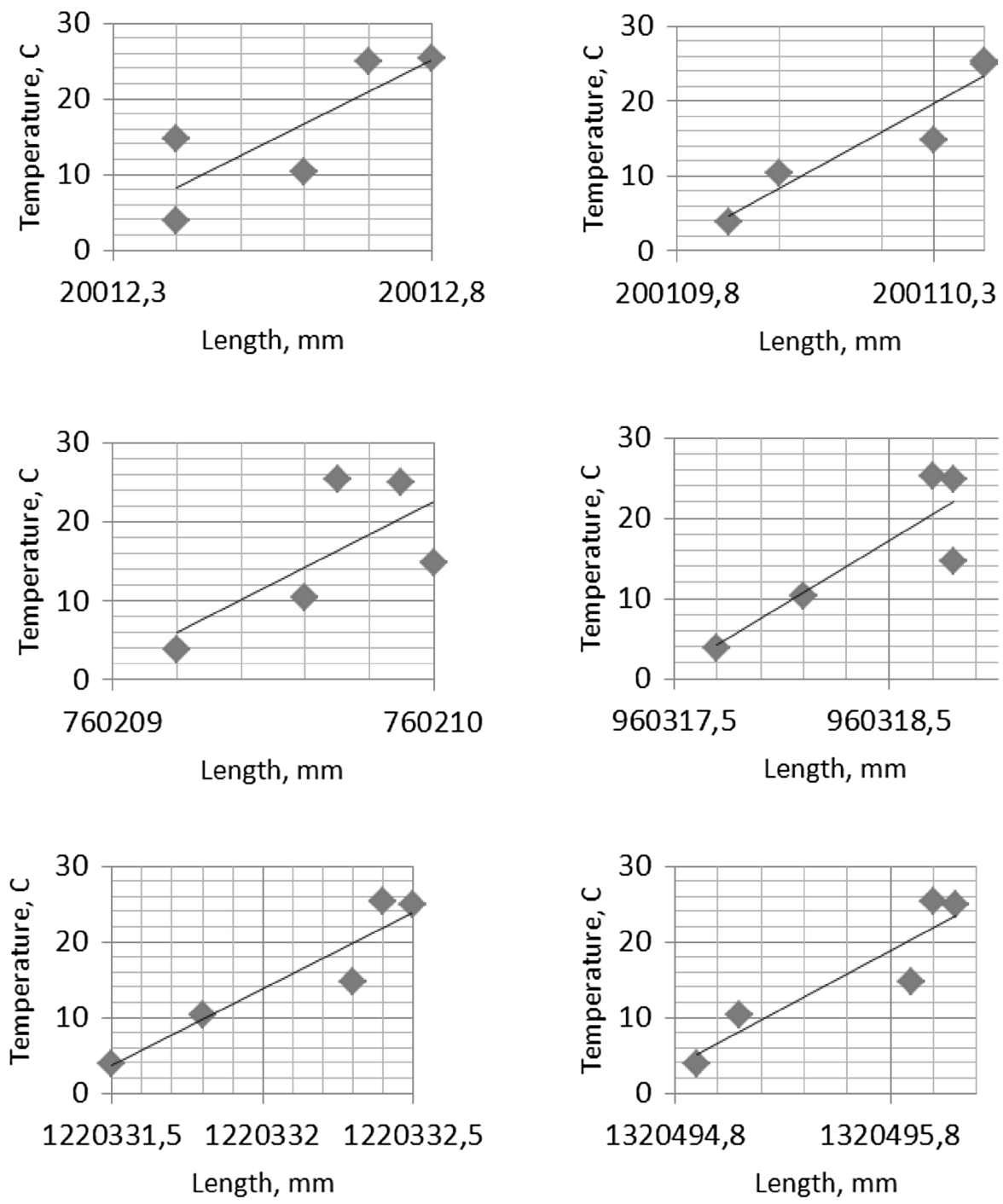

Fig. 7 Relations between the baseline length and the temperature (measurements of 1997-2014) 


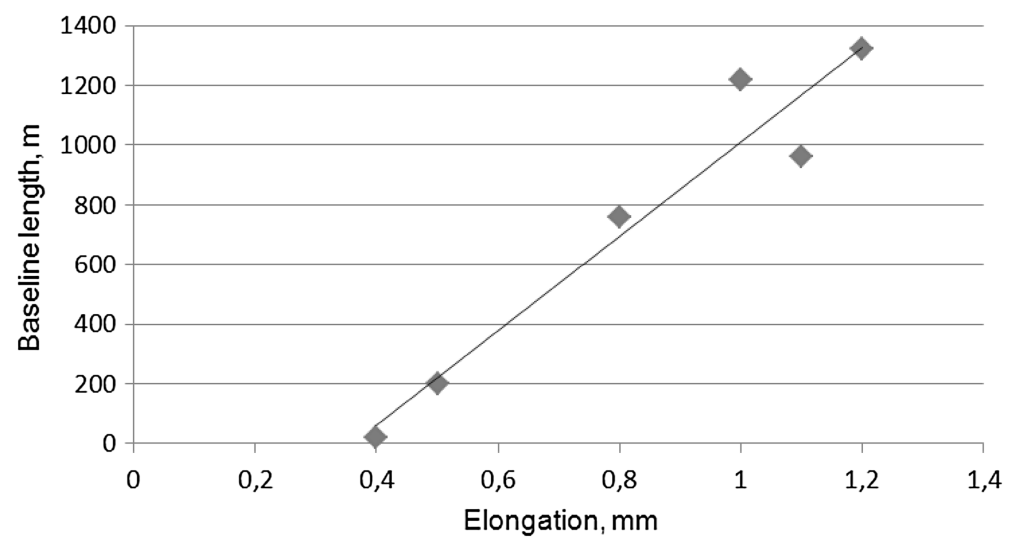

Fig. 8 The baseline elongation in relation to the baseline length

Table 1 Correlation coefficients for individual baselines

\begin{tabular}{lll}
\hline Length $(\mathrm{m})$ & Baseline & Correlation coefficient \\
\hline 20 & $5-6$ & 0.81 \\
200 & $4-6$ & 0.95 \\
760 & $3-4$ & 0.69 \\
960 & $3-6$ & 0.87 \\
1220 & $2-6$ & 0.94 \\
1320 & $1-6$ & 0.92 \\
\hline
\end{tabular}

determination is very temperature sensitive. The air pressure measurements are also important, but they vary less in time and therefore are easier to measure.

Numbers in the Table 1 show the correlation clearly. However, we assume that this is not the effect of the baseline thermal expansion. The available formulas for refraction correction are reliable and tested in numerous publications. We suppose that the uncertainty of the temperature measurements is the problematic part. The precise calibrated psychrometers, especially in unfavorable (sunny) weather conditions, are bound to have much larger uncertainty of the temperature observations than the uncertainty of the temperature measuring instruments.

If the temperature measured is too high in comparison with the real one, we get too long baseline lengths; this could be the most probable reason for the correlation shown above. During the measurements the thermometers of the psychrometers are in the shadow. Nevertheless, in sunny weather conditions the psychrometers under parasols "run too hot", compared with the "true" temperatures. Anyway, this does not completely clear out the correlation between the measured temperature and the determined baseline length because measurements in 2001 and 2008 were carried out in cloudy weather.

\section{Conclusions}

The Kyviškès Calibration Baseline was calibrated five times during the last two decades. The regular calibrations proved good stability of the pillars and reliability of the baseline. The length variation of the baseline sections during five measurement cycles is within 
\pm 0.3 and $\pm 0.6 \mathrm{~mm}$. The obtained total uncertainty of the baseline is in the interval between \pm 0.3 and $\pm 0.9 \mathrm{~mm}$. The thermal length variation of the Kyviškès Calibration Baseline is an interesting phenomenon, which has to be researched in the future. The Kyviškès Calibration Baseline measurements in 1997-2014 allowed for accumulating sufficient data set to be used for analysis of stability, repeatability, reproducibility and influence of the weather conditions. The experience that was gained may be useful worldwide for analogical baseline length determination during extreme differences in temperature. Meanwhile the authors are satisfied with the achieved results and plan to continue the regular calibrations and using of the baseline.

\section{References}

Būga A, Jokela J, Putrimas R, Zygmantienè E (2011) Traceability, stability and use of the Kyviškès calibration baseline - the first 10 years. In: Čygas D, Froehner KD (eds) The 8th international conference environmental engineering, selected papers, vol 3. pp 1301-1305

Dracup JF, Fronczek CJ, Tomlinson RW et al (2014) NOAA technical memorandum NOS NGS-8: establishment of calibration base lines, $26 \mathrm{p}$

Hazelton NWJ (2009) Instrument calibration for the 21st century. Presented at the MSPS 57th annual meeting, St. Cloud

Jokela J (2014) Length in geodesy_on metrological traceability of a geospatial measurement, vol 154. Publ. Finn. Geod. Inst.

Jokela J, Häkli P (2006) Current research and development at the Nummela Standard Baseline. XXIII FIG Congress, Munich

Jokela J, Häkli P (2010) Interference measurements of the Nummela Standard Baseline in 2005 and 2007 , vol 85. Kirkkonummi

Jokela J, Poutanen M (1998) The Väisälä baselines in Finland, vol 127. Publ. Finn. Geod. Inst., pp 5-43

Jokela J, Petroškevičius P, Tulevičius V (1999) Kyviškès Calibration Baseline. Reports of the FGI, 99:3

Jokela J, Häkli P, Būga A, Putrimas R (2009) On traceability of long distances. In: Proceedings Of XIX IMEKO world congress. fundamental and applied metrology, Lisbon, pp 1882-1887

Kukkamäki TJ (1978) Väisälä Interference Comparator. Publ. Finn. Geod. Inst. no. 87

Pollinger F, Meyer T, Beyer J, Doloca NR, Schellin W, Niemeier W, Jokela J, Hakli P, Abou-Zeid A, Meiners-Hagen K (2012) The upgraded PTB $600 \mathrm{~m}$ baseline: a high-accuracy reference for the calibration and the development of long distance measurement devices. Meas Sci Technol 23:094018. http://stacks.iop.org/MST/23/094018. (11 p)

Rüeger JM (1985) Traceability of electronic distance measurements to national standards. In: Proceedings of the 27th Australian survey congress, 23-30 March 1985, pp 149-163

Šlikas D (2013) Development of terrestrial laser scanners calibration methodology and scanning technology applications for ground surface modelling. Doctoral dissertation. VGTU 